\title{
Establishment of a murine, lipopolysaccharide- induced sepsis model for testing anaerobic exercise thresholds and early mobilization
}

\section{Yujiro Matsuishi}

Department of Emergency and Critical Care Medicine, Faculty of Medicine, University of Tsukuba, Tsukuba, Ibaraki, Japan https://orcid.org/0000-0001-6388-9263

\section{Nobutake Shimojo}

Department of Emergency and Critical Care Medicine, Faculty of Medicine, University of Tsukuba,

Tsukuba, Ibaraki, Japan

\section{Haruhiko Hoshino}

Department of Emergency and Critical Care Medicine, Faculty of Medicine, University of Tsukuba, Tsukuba, Ibaraki, Japan. Pediatric Intensive Care Unit, University of Tsukuba Hospital, Tsukuba, Ibaraki, Japan

\section{Yuki Enomoto}

Department of Emergency and Critical Care Medicine, Faculty of Medicine, University of Tsukuba, Tsukuba, Ibaraki, Japan. Department of Pediatrics, Faculty of Medicine, University of Tsukuba, Tsukuba, Ibaraki, Japan

\section{Bryan J. Mathis}

Faculty of Medicine, University of Tsukuba, Tsukuba, Ibaraki, Japan

\section{Sechang Oh}

Medical Sciences, Faculty of Medicine, University of Tsukuba, Tsukuba, Ibaraki, Japan

\section{Satoru Kawano}

Department of Emergency and Critical Care Medicine, Faculty of Medicine, University of Tsukuba,

Tsukuba, Ibaraki, Japan

\section{Kanae Myoenzono}

Graduate School of Comprehensive Human Sciences, University of Tsukuba, Ibaraki, Japan

\section{Seiji Maeda}

Faculty of Health and Sport Sciences, University of Tsukuba, Ibaraki, Japan

\section{Junichi Shoda}

Medical Sciences, Faculty of Medicine, University of Tsukuba, Tsukuba, Ibaraki, Japan

\section{Shigeaki Inoue}

Department of Disaster and Emergency and Critical Care Medicine, Kobe University Graduate School of Medicine, Kobe, Japan

Yoshiaki Inoue ( $\nabla$ yinoue@md.tsukuba.ac.jp ) 
Department of Emergency and Critical Care Medicine, Faculty of Medicine, University of Tsukuba, Tsukuba, Ibaraki, Japan https://orcid.org/0000-0001-6407-1965

\section{Research}

Keywords: Sepsis, Early mobilization, Translational study

Posted Date: July 29th, 2020

DOl: https://doi.org/10.21203/rs.3.rs-43539/v1

License: (9) This work is licensed under a Creative Commons Attribution 4.0 International License. Read Full License

Version of Record: A version of this preprint was published at Medicine in Drug Discovery on March 1st, 2021. See the published version at https://doi.org/10.1016/j.medidd.2020.100074. 


\section{Abstract}

Background: Several methods have been proposed to prevent post intensive care syndrome (PICS) after sepsis, including early mobilization, but controversy remains in mechanisms and outcomes. Translational studies are required to fully reveal the optimal exercise intensity during acute phase sepsis. The aim of this study is to establish a septic mouse model and and classify exercise intensi ties during the acute phase of sepsis.

Methods: Adult, male C57/B6 mice received lipopolysaccharide (LPS) injections (20mg/kg). We recorded survival rates and metabolic changes, such as resting energy expenditure (REE) compared with controls up to $72 \mathrm{~h}$ after LPS administration. We also observed vital signs (rectal temperature and weight change) and inflammation (TNF-aand IL-6). We detected exercise intensity via metabolic monitoring treadmill, analyzed the anaerobic threshold (AT) by V-Slope Method and classified the intensity levels according to American College of Sports Medicine (ACSM) guidelines.

Result: Around $30 \%$ of the mice survived $72 \mathrm{~h}$ after LPS induction with REE and rectal temperatures lowest at around 22-24h later (REE at $22 \mathrm{~h}: 2.26 \pm 0.34 \mathrm{kcal} /$ day $\mathrm{p}<0.05 \mathrm{vs}$. baseline; Rectal temperature at $24 \mathrm{~h}$ : $29.17 \pm 0.48^{\circ} \mathrm{C}, \mathrm{p}<0.05 \mathrm{vs}$. baseline). Gradual recovery was seen out to $72 \mathrm{~h}$. Blood concentrations of TNFa were highest at the $12 \mathrm{~h}$ timepoint $(41.23 \pm 24.39 \mathrm{pg} / \mathrm{ml}, \mathrm{p}<0.05 \mathrm{vs}$. baseline) and IL- 6 was highest at $24 \mathrm{~h}$ after LPS induction ( $1476.5 \pm 274.7 \mathrm{pg} / \mathrm{ml}, \mathrm{p}<0.05 \mathrm{vs}$. baseline). Using the $\mathrm{V}$-Slope method, we observed the AT at each timepoint (6h:14m/min, $12 \mathrm{~h}: 9 \mathrm{~m} / \mathrm{min}, 24 \mathrm{~h}: 4 \mathrm{~m} / \mathrm{min}, 36 \mathrm{~h}: 10 \mathrm{~m} / \mathrm{min}$, $48 \mathrm{~h}: 16 \mathrm{~m} / \mathrm{min}, 60 \mathrm{~h}: 20 \mathrm{~m} / \mathrm{min}, 72 \mathrm{~h}: 22 \mathrm{~m} / \mathrm{min}$ ) and classified these into very low intensity exercise training (VLIT), low intensity exercise training (LIT), or moderate intensity exercise training (MIT) at each timepoint.

Conclusion: We classified exercise intensities out to $72 \mathrm{~h}$ after sepsis recovery using a mouse model. These data may serve as a bridge to clinical studies to fill gaps in best practice for sepsis rehabilitation.

\section{Background}

Sepsis is a critical life-threatening condition with over 19 million people affected worldwide and a mortality reported at $26 \%(1)$. Even after discharge, one-third of sufferers die and, for those who survive longer than 6 months suffer(2) multiple complications, including cognitive dysfunction(3) and muscle weakness (ICU-acquired weakness [ICU-AW])(4). Recently, these complications have been well studied and named post intensive care syndrome (PICS) at the 2012 SCCM Conference(5).

Current sepsis best practice attempts to control mortality and quality of life and thus the relationship between sepsis and PICS has been targeted by the intensive care field as evidenced by several reported methods for preventing PICS. Early mobilization, or exercise after recovery, is a well-known prevention method to prevent sepsis complications (6) and the American College of Critical Care Medicine (ACCM) emphasizes that early mobilization plays a key role for preventing delirium(7). Early mobilization is defined as applied physical activity within the first 2 to 5 days of critical illness or injury(8), and a recent 
randomized, clinical study revealed that early mobilization during septic shock prevents muscle atrophy(9). Implicated pathways for muscle atrophy during sepsis include the mammalian target of rapamycin (MTor)(10), interleukin-6 (IL-6)(11), and tumor necrosis factor-alpha (TNF-a)(12). However, conflicting studies report that early mobilization is beneficial for preventing muscle weakness(9) but may increase mortality(13). Additionally, potential prognostic markers have recently been investigated in septic shock patients(6). Therefore, to reveal critically needed hard outcomes, including mortality and sepsis progression mechanisms, translational studies in humans and animal models are required. Thus, the aim of this study is to find the appropriate exercise intensity for early mobilization in a severe septic mouse model.

\section{Materials And Methods}

\section{Mouse Model}

Male C57/BL6 mice (24-26 g, 11 weeks old) were purchased from CLEA, Tokyo, Japan for use in this study. Sepsis was induced by the intraperitoneal (IP) administration of bacterial LPS from Escherichia coli strain 055: B5 (20 mg/ $\mathrm{kg})$ dissolved in sterile saline. This LPS-induced sepsis model has been used previously used to generate animal models of sepsis(14-16). Mice were kept on a $12 \mathrm{hr}: 12 \mathrm{hr} \mathrm{light:dark}$ schedule at an ambient temperature of $23 \pm 1^{\circ} \mathrm{C}$ under specific pathogen-free conditions.

\section{Time course of metabolism and survival experiment}

From our previously published experience with this LPS-induced sepsis model(14-16), 72h metabolism and $72 \mathrm{~h}$ survival analyses were performed using a metabolic cage that automatically calculates VO2 and VCO2 (Muromachi, Tokyo, Japan). The measurement interval was set at 3 minutes and cage air flow was set at $0.5 \mathrm{~L} / \mathrm{min}$. We used the hourly average of $\mathrm{VO} 2$ and VCO2 in our calculations. The cage was not opened during the observational period and standard laboratory chow (MF; Oriental Yeast, Tokyo, Japan) and tap water were provided ad libitum. We calculated the resting energy expenditure (REE) using Lusk's formula(17) as follows: $\mathrm{REE}=3.816 \times \mathrm{VO} 2+1.231 \times \mathrm{VCO} 2$.

\section{Time course of vital signs and inflammation}

To analyze the status of inflammation after LPS administration over 72 hours, mice were divided into 5 groups: controls $(n=10), 12 h(n=10), 24 h(n=10), 48 h(n=10)$ and $72 h(n=10)$ post-LPS administration. We measured rectal temperatures and weight loss rate plus we harvested blood to analyze representative inflammation proteins TNF- $a$ and IL -6 by enzyme-linked immunosorbent assay ( $R$ \& D Systems, Minneapolis, MN). 


\section{Anaerobic Threshold test and defining intensity of exercise in sepsis model}

The anaerobic threshold (AT) is the transition point from predominantly aerobic to anaerobic metabolism, (18) which occurs at around $60 \%$ of the maximum oxygen uptake capacity (max VO2)(19). With regard to intensity, we adopted recommendations of the American College of Sports Medicine (ACSM), which defines exercise over the AT ( $60 \%$ of the max V02) as vigorous, intensity of under one-third as very low intensity exercise training (VLIT), between one-third to two-thirds as low intensity training (VIT), and between two-thirds to the AT as moderate intensity training (MIT).(20) All mice underwent 30 minutes of treadmill exercise $(25 \mathrm{~m} / \mathrm{min})$ three times per week for one week to become accustomed to the exercise protocol and handling. We performed exercise experiments three times on the first day after LPS administration (6h, 12h, 24h after induced LPS), two times on the second day after LPS administration (36h, 48h after induced LPS) and on the third day after LPS administration (60h, 72h after induced LPS). A metabolic monitoring, motor-driven, two-lane treadmill chamber was used for AT testing. The exercise protocol started at $1 \mathrm{~m} / \mathrm{min}$ and the exercise intensity was then increased by $1 \mathrm{~m} / \mathrm{min}(1-10 \mathrm{~m} / \mathrm{min})$ every three minutes. From the $10 \mathrm{~m} / \mathrm{min}$ point, the exercise intensity was increased by $2 \mathrm{~m} / \mathrm{min}$ every three minutes up to the all-out value. We defined this all-out value as the point where mice could not keep running even with encouragement. Anaerobic Threshold (AT) was evaluated by Ventilation Threshold (VT), a representative method for estimating AT, and derived by the V-Slope Method, which evaluates the point at which the increase in carbon dioxide production (VCO2) is greater than the increase in oxygen uptake (VO2) $(21,22)$. Briefly, we used each speed point as a cut off and calculated aerobic exercise slope and anaerobic exercise. Then, total residuals were calculated (residuals of aerobic exercise slope and anaerobic exercise slope) and we defined the minimum total residuals cut point which indicated the best fit for the two variable lines as the AT point. (Figure 1) The R-squared fit value for each regression line is also shown in Figure 1.

\section{Experiment flow}

The total number of mice used in these experiments was eighty. Twenty mice were used to analyze metabolic differences between sepsis $(n=10)$ and controls $(n=10)$ within $72 h$ after LPS administration. Ten mice were used for the exercise tolerance experiment within $72 \mathrm{~h}$ after LPS administration. A total of fifty mice were used to analyze inflammation and vital signs in control $(n=10), 12 h(n=10), 24 h(n=10)$, 48h $(n=10)$ and $72 h(n=10)$ after LPS administration groups. The Institutional Review Board (IRB) of the University of Tsukuba Affiliated Hospital approved all aspects of the study (Approval \# 18-132) and we obeyed The PREPARE (Planning Research and Experimental Procedures on Animals: Recommendations for Excellence) guideline(23) for all the procedures.

\section{Statistical Analysis}


Results are expressed as mean \pm SE and, for parametric distribution, two-sided analysis of variance (ANOVA) testing was used. For non-parametric distribution among two groups, Kruskal-Wallis testing, followed by Steel-Dwass testing for multiple comparisons, was used. Survival data was analyzed by logrank testing and $p<0.05$ was considered statistically significant for all parameters. All statistics were performed in R software (http://www.r-project.org).

\section{Results}

\section{Time course of metabolism and survival experiment}

We evaluated survival after LPS administration over multiple timepoints until $72 \mathrm{~h}$. Within the LPS group, $70 \%$ of the mice died around $24 \mathrm{~h}$ after LPS administration and $30 \%$ survived while $100 \%$ of the control mice survived. $(p<0.01)$ As shown in Figure 2, REE in the control group was synchronized to circadian rhythms in the control group. However, REE in the LPS group dramatically decreased at roughly $12 \mathrm{~h}$ after LPS induction of inflammation (5.76 \pm 0.49$)$, was lowest at the $22 \mathrm{~h}$ post-LPS timepoint $(2.26 \pm 0.34)$ and gradually recovered, although not to baseline, at $24 \mathrm{~h}(2.26 \pm 0.34), 48 \mathrm{~h}(3.3 \pm 0.4)$ and at $72 \mathrm{~h}$ after LPS administration $(3.58 \pm 0.41)$.

\section{Time course of vital signs and inflammation}

Data of rectal temperatures and weight change rates until $72 \mathrm{~h}$ after LPS induction are shown in Figure 3. The average rectal temperature before LPS (baseline) was $37.31 \pm 0.17^{\circ} \mathrm{C}$ but dramatically decreased $12 \mathrm{~h}$ after LPS induction $\left(31.15 \pm 0.67^{\circ} \mathrm{C}, \mathrm{p}<0.05 \mathrm{vs}\right.$. baseline), was lowest $24 \mathrm{~h}$ after LPS induction $\left(29.17 \pm 0.48^{\circ} \mathrm{C}, \mathrm{p}<0.05\right.$ vs. baseline) and gradually recovered at $48 \mathrm{~h}\left(32.31 \pm 0.46,{ }^{\circ} \mathrm{C} p<0.05\right.$ vs. baseline, $p<0.05$ vs. $24 \mathrm{~h}$ after LPS induction) and $72 \mathrm{~h}$ timepoints $\left(34.04 \pm 0.28^{\circ} \mathrm{C}, \mathrm{p}<0.05 \mathrm{vs}\right.$. baseline, $p<0.05 \mathrm{vs}$. $24 \mathrm{~h}$ after LPS induction) although it did not return to baseline. Weight change rates were significantly decreased from the baseline at $12 \mathrm{~h}(92 \% \pm 0.5 \%, p<0.05$ vs. baseline), $24 \mathrm{~h}(90 \% \pm 0.5 \%, p<0.05$ vs. baseline), $48 \mathrm{~h}(83 \% \pm 0.6 \%, p<0.05$ vs. baseline, $p<0.05$ vs. $12 \mathrm{~h}$ after LPS induction, $p<0.05$ vs. $24 \mathrm{~h}$ after LPS induction), and $72 \mathrm{~h}$ post-LPS timepoints $(76 \% \pm 0.5 \%, p<0.05$ vs. baseline, $p<0.05$ vs. $12 \mathrm{~h}$ after LPS induction, $p<0.05$ vs. $24 \mathrm{~h}$ after LPS induction, $p<0.05$ vs. $48 \mathrm{~h}$ after LPS induction).

Serum TNF-aand IL -6 , representative inflammatory cytokines, experienced dramatic LPS-induced changes as shown in Figure 4. TNF-alevels were highest $12 \mathrm{~h}$ after LPS induction $(41.23 \pm 24.39 \mathrm{pg} / \mathrm{ml}$, $p<0.05$ vs. baseline) and decreased by the $24 \mathrm{~h}$ timepoint $(14.37 \pm 7.85 \mathrm{pg} / \mathrm{ml}, \mathrm{p}<0.05 \mathrm{vs}$. baseline). Levels then normalized $48 \mathrm{~h}$ after LPS induction. IL-6, on the other hand, significantly increased $12 \mathrm{~h}$ after LPS induction ( $1133.8 \pm 182.4 \mathrm{pg} / \mathrm{ml}, \mathrm{p}<0.05 \mathrm{vs}$. baseline, $\mathrm{p}<0.05 \mathrm{vs}$. $72 \mathrm{~h}$ after LPS induction), was highest at $24 \mathrm{~h}$ after LPS induction $(1476.5 \pm 274.7 \mathrm{pg} / \mathrm{ml}, \mathrm{p}<0.05 \mathrm{vs}$. baseline, $\mathrm{p}<0.05 \mathrm{vs}$. $48 \mathrm{~h}$ after LPS induction, $\mathrm{p}<0.05 \mathrm{vs}$. $72 \mathrm{~h}$ after LPS induction) but significantly decreased at the $48 \mathrm{~h}$ timepoint $(277.7 \pm 160.8 \mathrm{pg} / \mathrm{ml}$, $p<0.05$ vs. baseline, $p<0.05$ vs. $24 \mathrm{~h}$ after LPS induction) and did not fully normalize until $72 \mathrm{~h}$ after LPS administration ( $56.6 \pm 24.2 \mathrm{pg} / \mathrm{ml}, p<0.05 \mathrm{vs}$. baseline, $p<0.05 \mathrm{vs}$. $24 \mathrm{~h}$ after LPS induction). 


\section{Anaerobic Threshold (AT) test and defining intensity of exercise in sepsis model}

AT test results are shown in Figures 5,6, and 7. Overall, the AT threshold decreased $24 \mathrm{~h}$ after LPS induction and gradually recovered out to the $72 \mathrm{~h}$ timepoint. At $6 \mathrm{~h}$ after LPS induction, AT, as defined by the minimum total residuals cutoff point, was found to be $14 \mathrm{~m} / \mathrm{min}$ and this dropped to $9 \mathrm{~m} / \mathrm{min}$ at the $12 \mathrm{~h}$ timepoint and $4 \mathrm{~m} / \mathrm{min}$ at the $24 \mathrm{~h}$ timepoint. However, it recovered to $10 \mathrm{~m} / \mathrm{min}$ at the $36 \mathrm{~h}$ timepoint, $16 \mathrm{~m} / \mathrm{min}$ at the $48 \mathrm{~h}$ timepoint, $20 \mathrm{~m} / \mathrm{min}$ at the $60 \mathrm{~h}$ timepoint and $22 \mathrm{~m} / \mathrm{min}$ at the $72 \mathrm{~h}$ timepoint.

From these results, we classified activity into either VLIT (less than one-third the intensity of AT), LIT (from one-third to two-thirds the intensity of AT) or MIT (from two-thirds the intensity of AT to max AT) as follows: VLIT: $0 \sim 4 \mathrm{~m} / \mathrm{min}$, LIT: $5 \sim 9 \mathrm{~m} / \mathrm{min}$, MIT: $10 \sim 14 \mathrm{~m} / \mathrm{min}$ at $6 \mathrm{~h}$ after LPS induction; VLIT: $0 \sim 3$ $\mathrm{m} / \mathrm{min}$, LIT: $4 \sim 6 \mathrm{~m} / \mathrm{min}$, MIT: $7 \sim 9 \mathrm{~m} / \mathrm{min}$ at $12 \mathrm{~h}$ after LPS induction; VLIT: $0 \sim 1 \mathrm{~m} / \mathrm{min}$, LIT: $2 \mathrm{~m} / \mathrm{min}$, MIT: $3 \sim 4 \mathrm{~m} / \mathrm{min}$ at $24 \mathrm{~h}$ after LPS induction; VLIT: $0 \sim 3 \mathrm{~m} / \mathrm{min}$, LIT: $4 \sim 6 \mathrm{~m} / \mathrm{min}$, MIT: $7 \sim 10 \mathrm{~m} / \mathrm{min}$ at $36 \mathrm{~h}$ after LPS induction: VLIT: $0 \sim 5 \mathrm{~m} / \mathrm{min}$, LIT: $6 \sim 10 \mathrm{~m} / \mathrm{min}$, MIT: $11 \sim 16 \mathrm{~m} / \mathrm{min}$ at $48 \mathrm{~h}$ after LPS induction; VLIT: $0 \sim 6 \mathrm{~m} / \mathrm{min}$, LIT: $7 \sim 13 \mathrm{~m} / \mathrm{min}$, MIT: $14 \sim 20 \mathrm{~m} / \mathrm{min}$ at $60 \mathrm{~h}$ after LPS induction; and VLIT: $0 \sim 8 \mathrm{~m} / \mathrm{min}$, LIT: $9 \sim 16 \mathrm{~m} / \mathrm{min}$, MIT: $17 \sim 22 \mathrm{~m} / \mathrm{min}$ at $72 \mathrm{~h}$ after LPS induction. (Figure 8)

\section{Discussion}

\section{Discussion}

This study is the first to reveal the effect on exercise capacity in the acute phase of a murine, LPSinduced sepsis model. Several animal studies reported on exercise before the onset of $\operatorname{sepsis}(24,25)$, but did not fully reveal effects of sepsis on exercise capacity that would be useful in exploring benefits of early mobilization.

Our LPS-induced sepsis model showed the lowest metabolic condition at the $22 \mathrm{~h}$ timepoint after a reactive TNF-aand IL- 6 cytokine surge $12 \mathrm{~h}$ after induction that peaked at the $24 \mathrm{~h}$ timepoint(26). Rectal temperature changes supported this observation and the protective immune reaction(27), as seen in previous reports, resulted in a lower metabolic condition/REE(28). The $70 \%$ mortality seen $24 \mathrm{~h}$ after LPS administration is also in line with literature reports. For survivors, the $24 \mathrm{~h}$ to $72 \mathrm{~h}$ post-LPS timepoint sees improvements in inflammation status and AT but weight loss persists. This time course after sepsis is well described in humans,(29) indicating that our model is suitable for simulating the septic cascade.

In line with the inflammation results, the observed AT threshold diminished up to $24 \mathrm{~h}$ after LPS induction but gradually recovered from then until the $72 \mathrm{~h}$ timepoint. As a new diagnostic criterion for sepsis includes increases in lactate levels attributed to anaerobic metabolism, this seems to be in line with the 3day recovery needed for AT.(30) Excess lactate caused by inflammation within the muscle tissue could adversely affect VO2 max and decrease fitness as seen in our results. Additionally, IL-6 is thought to be a 
suitable marker for septic response and, in our model, IL -6 and AT changes occurred in parallel which indicates that appropriate exercise intensities progress in a condition-dependent fashion. Surprisingly, IL6 is recognized as a myokine (a cytokine released by myocytes in muscle tissue) and plays roles in autocrine regulation of metabolism in muscle and other endocrine organs.(31) Skeletal muscle has a unique function as an acute sensor of external stress signals via IL-6 expression(32). In particular, during sepsis induced by LPS, the liver contains the major portion of tissue-bound LPS ( 40\%) but muscle contains the second highest tissue-bound LPS ( 5\%)(33). This relationship between muscle condition and IL-6 also supports the change in AT we observed over $72 \mathrm{~h}$ after LPS induction.

Randomized, controlled trials in for early phase exercise in severely ill patients have utilized electrical muscle stimulation (EMS)(13), ambulation(13), walking(34), and therapeutic exercises up to MIT to improve survival rate and prevent subsequent complications. However, paradoxically, even though the stepwise progression of rehabilitation within these studies progresses from VLIT to MIT, there are scarce reports on which levels were most effective. Meanwhile, the effect of VLIT and LIT to improve health outcomes was epidemiologically examined by the National Health and Nutrition Examination Survey (NHANES)in the elderly(35). Cellular-level experiments showed that LIT improved the regenerative capacity of skeletal muscle in humans(36) and short-distance, voluntary exercise activated brain-derived neurotrophic factor (BDNF) signaling in the hippocampus, enhancing spatial memory in rats(37). A functional MRI study in humans found that only 10 minutes of VLIT was needed to improve hippocampal function(38). The clear benefits of exercise in the acute phase of sepsis still need to be revealed both clinically and fundamentally, but VLIT and LIT (e.g., sitting at the edge of a bed, standing/transfer, ADL Training) may be as valuable as MIT for improving the vital physical and cognitive functions of sepsis survivors.

Clinically, sepsis may adversely affect physical, cognitive, psychological function in survivors, a condition known as post-intensive care syndrome (PICS)(5). Various studies have sought the effect of early rehabilitation on mortality and $\operatorname{PICS}(34,39,40)$ while several systematic and Cochrane reviews $(41-43)$ have been conducted over the past three years but none have fully revealed associations between early rehabilitation and outcomes. These studies are weakened by a reliance on observational studies (and subsequent inability to remove demographic bias) since randomized, controlled trials are difficult to conduct in sepsis cases. (44) On the other hand, animal studies allow for precise control of variables that remove bias in results $(45,46)$. There has been a recent push for animal studies that reveal not only physical and cognitive changes in sepsis, but also psychological function, represented as post-traumatic stress disorder, using mice models(47-51). Our establishment of a mouse model that allowed for exploration into the appropriateness of early mobilization and could easily be adapted for translational studies in sepsis that explore clinically relevant biomarkers (such as lactate) or exercise-related parameters.

\section{Conclusion}


We established an LPS-induced, severe sepsis mouse model appropriate for evaluation of early mobilization in sepsis and classified exercise intensities (VLIT, LIT, MIT) for 72h after LPS administration.

\section{Declarations}

\section{Acknowledgments}

None

\section{Funding information}

This work was supported by the Grant-in-Aid for Scientific Research in Japan (16K20034).

\section{Ethical Approval and Consent to participate}

The Institutional Review Board (IRB) of the University of Tsukuba Affiliated Hospital approved all aspects of the study (Approval \# 18-132).

\section{Authors' contributions}

YM designed the study and carried out sample collection, data analysis, and wrote the manuscript. NS, $\mathrm{HH}, \mathrm{KM}$ and YE participated in sample collection. SO, JS and SM support study management, and SK,SI and YI participated in designing study. BM support writing manuscript. All authors read and approved the final manuscript.

\section{Competing interests}

None.

\section{Availability of supporting data}

The datasets used and/or analyzed during the present study are available from the corresponding author on reasonable request.

\section{Consent for publication}

Not applicable 


\section{References}

1. Sepsis H, Fleischmann C: Assessment of Global Incidence and Mortality of. 2016.

2. Yende S, Austin S, Rhodes A, et al.: Long-Term Quality of Life Among Survivors of Severe Sepsis: Analyses of Two International Trials. Crit Care Med 2016; 44:1461-7

3. Calsavara AJC, Costa PA, Nobre V, et al.: Factors Associated with Short and Long Term Cognitive Changes in Patients with Sepsis. Sci Rep 2018; 8:1-10

4. Kress JP, Hall JB: ICU-Acquired Weakness and Recovery from Critical Illness. N Engl J Med 2014; 370:1626-1635

5. Needham DM, Davidson J, Cohen $\mathrm{H}$, et al.: Improving long-term outcomes after discharge from intensive care unit. Crit Care Med 2012; 40:502-509

6. Govindan S, Iwashyna TJ, Odden A, et al.: Mobilization in Severe Sepsis: An Integrative Review Sushant. J Hosp Med 2016; 10:54-59

7. Devlin JW, Skrobik Y, Gélinas C, et al.: Clinical Practice Guidelines for the Prevention and Management of Pain, Agitation/Sedation, Delirium, Immobility, and Sleep Disruption in Adult Patients in the ICU. 2018.

8. Hodgson CL, Berney S, Harrold M, et al.: Clinical review: Early patient mobilization in the ICU. Crit Care 2012; $17: 1-7$

9. Hickmann CE, Castanares-Zapatero D, Deldicque L, et al.: Impact of very early physical therapy during septic shock on skeletal muscle: A randomized controlled trial. Crit Care Med 2018; 46:14361443

10. Frost RA, Lang CH: mTOR signaling in skeletal muscle during sepsis and inflammation: Where does it all go wrong? Physiology 2011; 26:83-96

11. Muñoz-Cánoves P, Scheele C, Pedersen BK, et al.: Interleukin-6 myokine signaling in skeletal muscle: A double-edged sword? FEBS J 2013; 280:4131-4148

12. Lang CH, Frost RA: Sepsis-induced suppression of skeletal muscle translation initiation mediated by tumor necrosis factor a. Metabolism 2007; 56:49-57

13. Kayambu G, Boots R, Paratz J: Early physical rehabilitation in intensive care patients with sepsis syndromes: a pilot randomised controlled trial. Intensive Care Med 2015; 41:865-874

14. Jesmin S, Gando S, Matsuda N, et al.: Temporal changes in pulmonary expression of key procoagulant molecules in rabbits with endotoxin-induced acute lung injury: Elevated expression levels of protease-activated receptors. Thromb Haemost 2004; 92:966-979

15. Shimojo N, Jesmin S, Zaedi S, et al.: Alterations of gene expressions of preproET-1 and ET receptors in brains of endotoxemic Sprague-Dawley rats. Exp Biol Med (Maywood) 2006; 231:1058-63

16. Matsuishi Y, Jesmin S, Kawano S, et al.: Landiolol hydrochloride ameliorates acute lung injury in a rat model of early sepsis through the suppression of elevated levels of pulmonary endothelin-1. Life Sci $2016 ; 166: 27-33$ 
17. Lusk G: The elements of the science of nutrition. (4th ed.). WB Saunders, Philadelphia, 1928;

18. Wasserman K, Mcllroy MB: Detecting the threshold of anaerobic metabolism in cardiac patients during exercise. Am J Cardiol 1964; 14:844-852

19. Wasserman K, Hansen JE SD: Physiology of Exercise. Philadelphia, PA: Lippincott Williams \& Wilkins; 2005.

20. Pescatello LSAC of SM: ACSM's guidelines for exercise testing and prescription. 9th ed. Philadelphia: Wolters Kluwer/Lippincott Williams \& Wilkins Health; 2014.

21. Schneider DA, Phillips SE, Stoffolano S: The simplified V-slope method of detecting the gas exchange threshold. Med Sci Sports Exerc 1993; 25:1180-4

22. Bouquet J, Li T, Gardy JL, et al.: Whole blood human transcriptome and virome analysis of ME/CFS patients experiencing post-exertional malaise following cardiopulmonary exercise testing. PLoS One 2019; 14

23. Smith AJ, Clutton RE, Lilley E, et al.: PREPARE: guidelines for planning animal research and testing. Lab Anim 2018; 52:135-141

24. Coelho CW, Jannig PR, Souza AB De, et al.: Exercise training prevents skeletal muscle damage in an experimental sepsis model. Clinics (Sao Paulo) 2013; 68:107-14

25. Sossdorf M, Fischer J, Meyer S, et al.: Physical exercise induces specific adaptations resulting in reduced organ injury and mortality during severe polymicrobial sepsis. Crit Care Med 2013; 41:e24655

26. Yimin, Kohanawa M: A Regulatory Effect of the Balance between TNF-a and IL-6 in the Granulomatous and Inflammatory Response to Rhodococcus aurantiacus Infection in Mice . $J$ Immunol 2006; 177:642-650

27. Harden LM, du Plessis I, Poole S, et al.: Interleukin-6 and leptin mediate lipopolysaccharide-induced fever and sickness behavior. Physiol Behav 2006; 89:146-155

28. Granger JI, Ratti PL, Datta SC, et al.: Sepsis-induced morbidity in mice: Effects on body temperature, body weight, cage activity, social behavior and cytokines in brain. Psychoneuroendocrinology 2013; 38:1047-1057

29. Delano MJ, Ward PA: The immune system's role in sepsis progression, resolution, and long-term outcome. Immunol Rev 2016; 274:330-353

30. Lee SM, An WS: New clinical criteria for septic shock: serum lactate level as new emerging vital sign. $J$ Thorac Dis 2016; 8:1388-1390

31. Pedersen BK, Steensberg A, Fischer C, et al.: Searching for the exercise factor: Is IL-6 a candidate? J Muscle Res Cell Motil 2003; 24:113-119

32. Welc SS, Clanton TL: The regulation of interleukin-6 implicates skeletal muscle as an integrative stress sensor and endocrine organ. Exp Physiol 2013; 98:359-371

33. Mathison JC, Ulevitch RJ, Fletcher JR, et al.: The distribution of lipopolysaccharide in normocomplementemic and C3-depleted rabbits and rhesus monkeys. Am J Patho/ 1980; 101:245- 
34. Brummel NE, Girard TD, Ely EW, et al.: Feasibility and safety of early combined cognitive and physical therapy for critically ill medical and surgical patients: The Activity and Cognitive Therapy in ICU (ACTICU) trial. Intensive Care Med 2014; 40:370-379

35. Loprinzi PD, Lee H, Cardinal BJ: Evidence to support including lifestyle light-intensity recommendations in physical activity guidelines for older adults. Am J Heal Promot 2015; 29:277284

36. Pietrangelo T, Di Filippo ES, Mancinelli R, et al.: Low intensity exercise training improves skeletal muscle regeneration potential. Front Physiol 2015; 6:1-10

37. Lee MC, Okamoto M, Liu YF, et al.: Voluntary resistance running with short distance enhances spatial memory related to hippocampal BDNF signaling. J Appl Physio/ 2012; 113:1260-1266

38. Suwabe K, Byun K, Hyodo K, et al.: Rapid stimulation of human dentate gyrus function with acute mild exercise. Proc Natl Acad Sci U S A 2018; 115:10487-10492

39. Denehy L, Skinner EH, Edbrooke L, et al.: Exercise rehabilitation for patients with critical illness: $A$ randomized controlled trial with 12 months of follow-up. Crit Care 2013; 17:1-12

40. Hodgson CL, Bailey M, Bellomo R, et al.: A binational multicenter pilot feasibility randomized controlled trial of early goal-directed mobilization in the ICU. Crit Care Med 2016; 44:1145-1152

41. Okada Y, Unoki T, Matsuishi Y, et al.: Early versus delayed mobilization for in- hospital mortality and health-related quality of life among critically ill patients: a systematic review and meta-analysis. 2019; $1-9$

42. Tipping CJ, Harrold M, Holland A, et al.: The effects of active mobilisation and rehabilitation in ICU on mortality and function: a systematic review. Intensive Care Med 2017; 43:171-183

43. Doiron KA, Hoffmann TC, Beller EM: Early intervention (mobilization or active exercise) for critically ill adults in the intensive care unit. Cochrane Database Syst Rev 2018; 18:21398-21411

44. Ross S, Grant A, Counsell C, et al.: Barriers to Participation in Randomised Controlled Trials. J Clin Epidemiol 1999; 52:1143-1156

45. Pound $P$, Ritskes-Hoitinga M: Is it possible to overcome issues of external validity in preclinical animal research? Why most animal models are bound to fail. J Trans/ Med 2018; 16:1-8

46. Leenaars $\mathrm{CHC}$, Kouwenaar C, Stafleu FR, et al.: Animal to human translation: A systematic scoping review of reported concordance rates. J Trans/ Med 2019; 17:1-22

47. Borghans B: Animal models for posttraumatic stress disorder: An overview of what is used in research. World J Psychiatry 2015; 5:387

48. Whitaker AM, Gilpin NW, Edwards S: Animal models of post-traumatic stress disorder and recent neurobiological insights. Behav Pharmacol 2014; 25:398-409

49. Richter-Levin G, Stork O, Schmidt M V.: Animal models of PTSD: a challenge to be met. Mol Psychiatry 2019; 24:1135-1156 
50. Pinna G: Animal models of PTSD: The socially isolated mouse and the biomarker role of allopregnanolone. Front Behav Neurosci 2019; 13:1-16

51. Toropova KA, Anokhin K V.: Modeling of Post-Traumatic Stress Disorder in Mice: Nonlinear Relationship with the Strength of the Traumatic Event. Neurosci Behav Physiol 2019; 49:875-886

\section{Figures}

Example of the figure of V-slope and exercise intensity

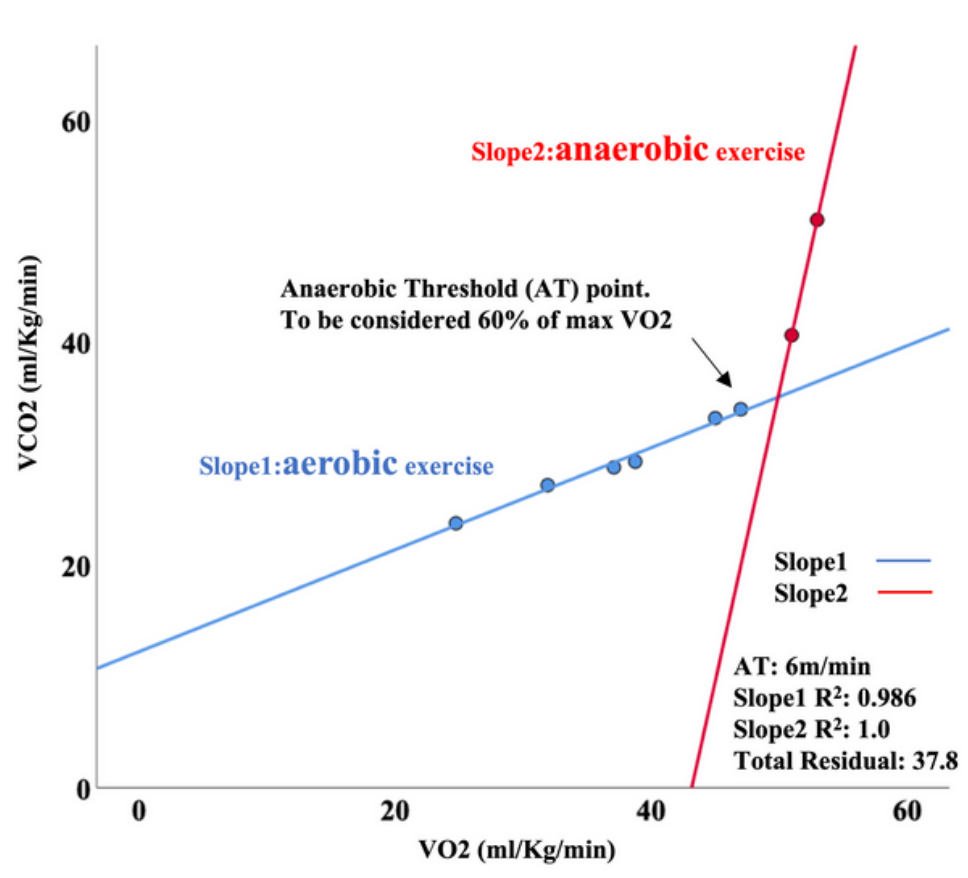

\begin{tabular}{|c|c|c|c|c|c|c|}
\hline \multirow{3}{*}{ VLIT } & Speed & Vo2 & $\mathrm{Vco} 2$ & $\begin{array}{c}\text { Slope } 1 \\
\text { residuals }\end{array}$ & $\begin{array}{c}\text { Slope } 2 \\
\text { residuals }\end{array}$ & $\begin{array}{c}\text { Total } \\
\text { residuals }\end{array}$ \\
\hline & $1 \mathrm{~m} / \mathrm{min}$ & 24.7 & 23.7 & - & - & - \\
\hline & $2 \mathrm{~m} / \mathrm{min}$ & 31.9 & 27.1 & 0 & 68.7 & 68.7 \\
\hline \multirow{2}{*}{ LIT } & $3 \mathrm{~m} / \mathrm{min}$ & 37 & 28.7 & 0.1 & 97.4 & 97.5 \\
\hline & $4 \mathrm{~m} / \mathrm{min}$ & 38.7 & 29.2 & 0.2 & 92.8 & 93 \\
\hline \multirow{2}{*}{ MIT } & $5 \mathrm{~m} / \mathrm{min}$ & 45 & 33.1 & 0.8 & 77 & 77.8 \\
\hline & $6 \mathrm{~m} / \mathrm{min}$ & 47 & 33.9 & 0.9 & 36.9 & $37.8^{*}$ \\
\hline \multirow{3}{*}{$\mathbf{A T}$} & $7 \mathrm{~m} / \mathrm{min}$ & 50.9 & 40.6 & - & - & - \\
\hline & $8 \mathrm{~m} / \mathrm{min}$ & 52.9 & 50.9 & - & - & - \\
\hline & & $\begin{array}{l}* \text { most fitted } \\
\text { (Minimum resi }\end{array}$ & $\begin{array}{l}\text { oint : Ana } \\
\text { duals of am }\end{array}$ & $\begin{array}{l}\text { aerobic Thr } \\
\text { nount of the }\end{array}$ & $\begin{array}{l}\text { reshold } \\
\text { Slope 1's an }\end{array}$ & Ad Slope 2's ) \\
\hline \multicolumn{7}{|c|}{ We defined under one third of the intensity of AT as VLIT } \\
\hline Low & intensity & exercise trainin & (LIT) & & & \\
\hline
\end{tabular}

Moderate intensity exercise training (MIT)

We defined over two third of the intensity of AT to the intensity of AT

\section{Figure 1}

Example V-slope and exercise intensity 
A. Survival rate

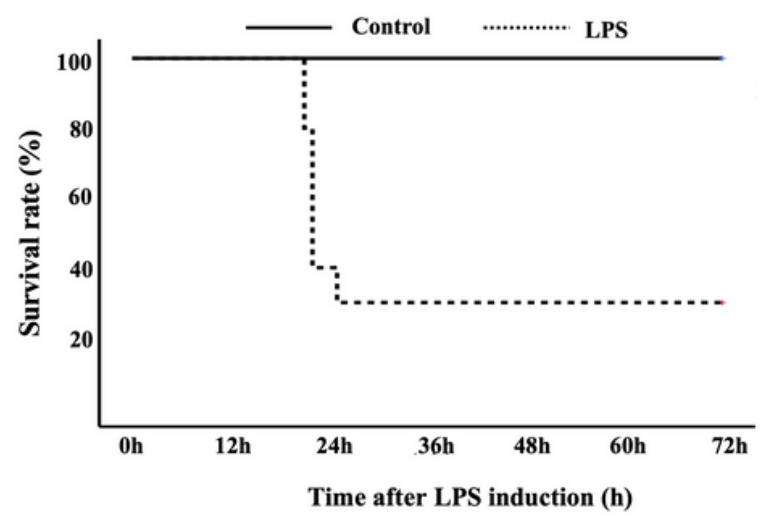

Time after LPS induction (h)

Number of subjects at each measurement time point

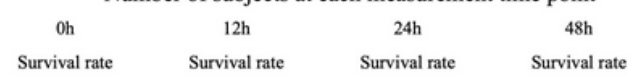

Control $\quad 100 \%$

LPS $\quad 100 \%$
$100 \%$

$100 \%$
$100 \% \quad 100 \%$

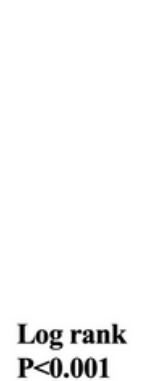

B. Transition of metabolism

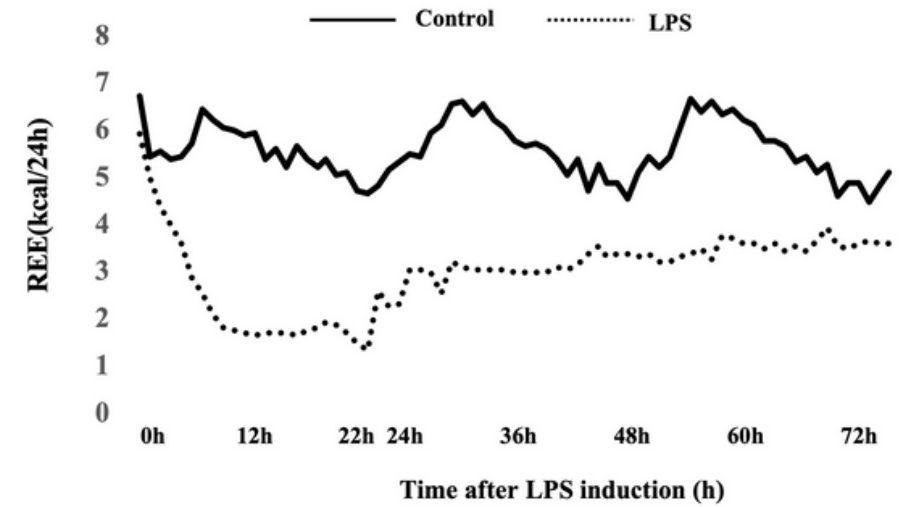

$72 \mathrm{~h}$
Survival rate

Number of subjects at each measurement time point

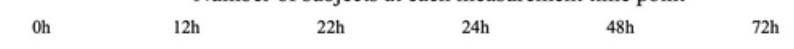
$\begin{array}{lllllllllll}\text { REE } & \text { SE } & \text { REE } & \text { SE } & \text { REE } & \text { SE } & \text { REE } & \text { SE } & \text { REE } & \text { SE } & \text { REE }\end{array}$ $100 \%$ $\begin{array}{lll}\text { Control } & 6.19 & 0.57\end{array}$ $5.76 \quad 0.49$ $\begin{array}{ll}5.07 & 0.45\end{array}$ $5.58 \quad 0.49$ $\begin{array}{llll}5.55 & 0.52 & 5.64 & 0.59\end{array}$ $30 \%$

\section{Figure 2}

Survival rate and transition of metabolism Hourly average number of VO2 and VCO2 was used to calculate the resting energy expenditure (REE) using Lusk's formula.

\section{A. Rectal temperature}
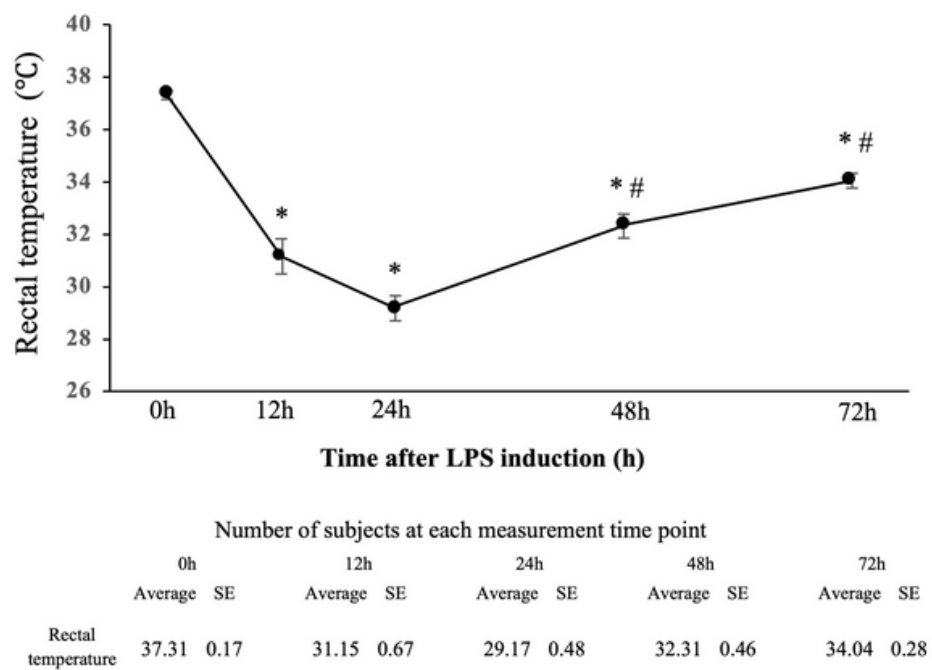

${ }^{*} \mathrm{p}<0.05$ vs. control, ${ }^{+} \mathrm{p}<0.05$ vs. LPS induced $12 \mathrm{~h}$.

$\# \mathrm{p}<0.05$ vs. LPS induced $24 \mathrm{~h}$. $\S \mathrm{p}<0.05$ vs. LPS induced $48 \mathrm{~h}$.
B. Weight change rate
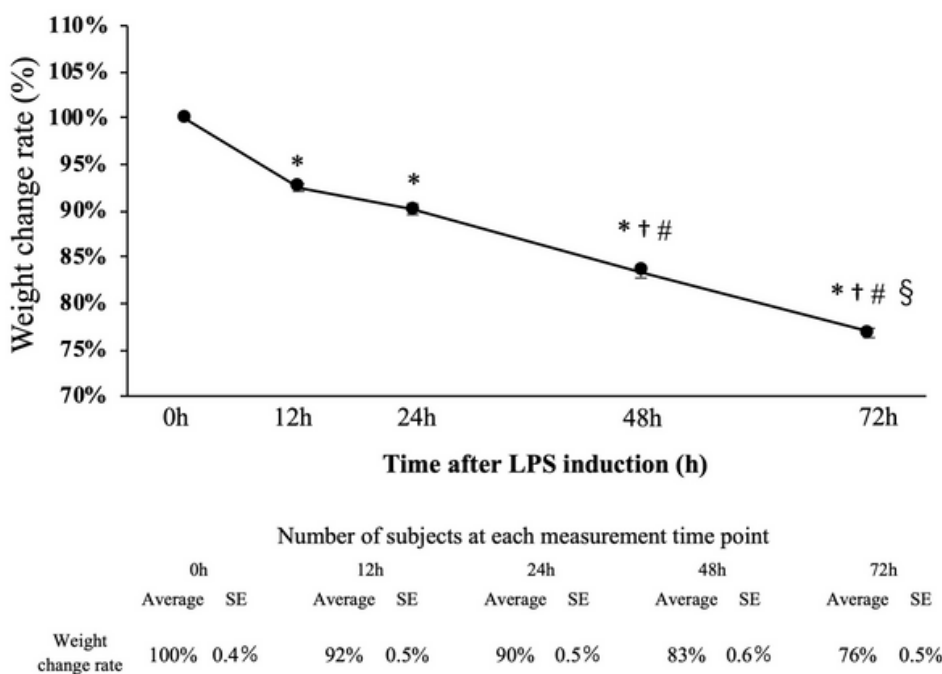

${ }^{*} \mathrm{p}<0.05$ vs. control, ${ }^{+} \mathrm{p}<0.05$ vs. LPS induced $12 \mathrm{~h}$.

$\# \mathrm{p}<0.05$ vs. LPS induced $24 \mathrm{~h}$. $\S \mathrm{p}<0.05$ vs. LPS induced $48 \mathrm{~h}$.

Figure 3

Rectal temperature and weight change rate 
A. Blood TNF- $\alpha$
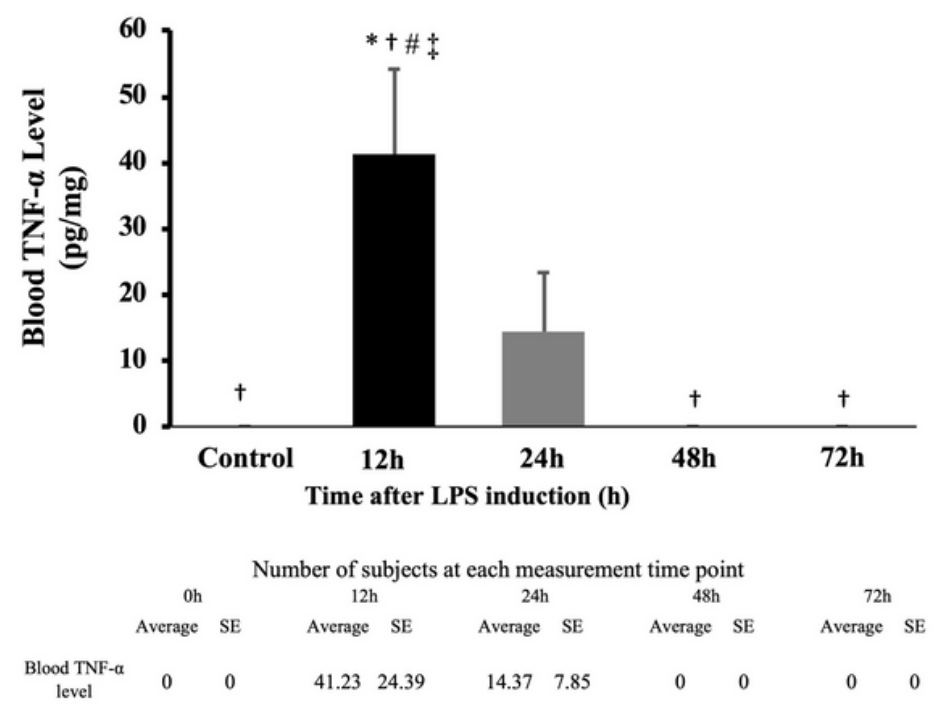

${ }^{*} \mathrm{p}<0.05$ vs. control, ${ }^{+} \mathrm{p}<0.05$ vs. LPS induced $12 \mathrm{~h}$. \# $\mathrm{p}<0.05$ vs. LPS induced $24 \mathrm{~h}$.

$\S \mathrm{p}<0.05$ vs. LPS induced $48 \mathrm{~h}$. $\ddagger \mathrm{p}<0.05$ vs. LPS induced $72 \mathrm{~h}$.

\section{B. Blood IL-6}

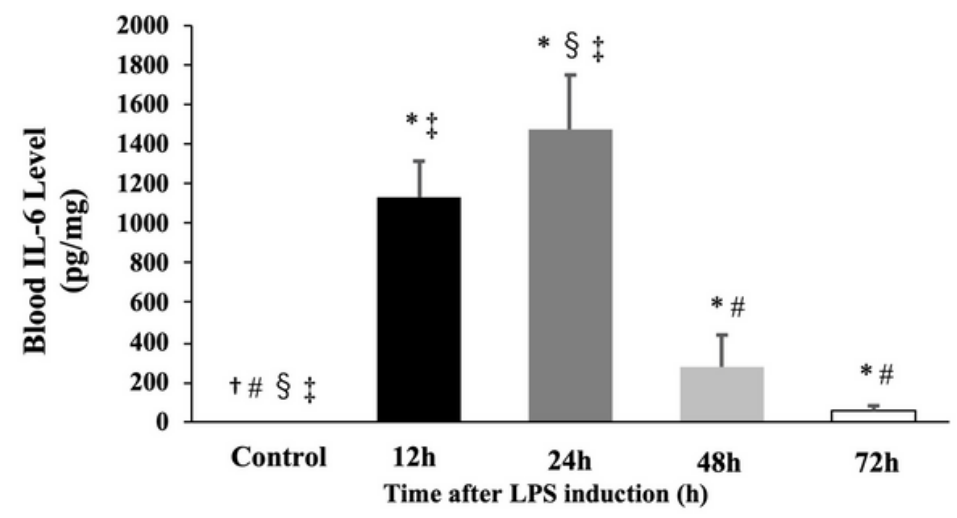

\begin{tabular}{|c|c|c|c|c|c|c|c|c|c|c|}
\hline & \multicolumn{10}{|c|}{ Number of subjects at each measurement time point } \\
\hline & \multicolumn{2}{|l|}{$0 \mathrm{~h}$} & \multicolumn{2}{|c|}{$12 \mathrm{~h}$} & \multicolumn{2}{|c|}{$24 \mathrm{~h}$} & \multicolumn{2}{|c|}{$48 \mathrm{~h}$} & \multicolumn{2}{|c|}{$72 \mathrm{~h}$} \\
\hline & Average & SE & Average & $\mathrm{SE}$ & Average & $\mathrm{SE}$ & Average & $\mathrm{SE}$ & Average & $\mathrm{SE}$ \\
\hline $\begin{array}{c}\text { Blood IL-6 } \\
\text { level }\end{array}$ & 0 & 0 & 1133.8 & 182.4 & 1476.5 & 274.7 & 277.7 & 160.8 & 56.6 & 24.2 \\
\hline
\end{tabular}

${ }^{*} \mathrm{p}<0.05$ vs. control, ${ }^{+} \mathrm{p}<0.05$ vs. LPS induced $12 \mathrm{~h} . \# \mathrm{p}<0.05$ vs. LPS induced $24 \mathrm{~h}$.

$\S \mathrm{p}<0.05$ vs. LPS induced $48 \mathrm{~h}$. $\ddagger \mathrm{p}<0.05$ vs. LPS induced $72 \mathrm{~h}$.

\section{Figure 4}

Inflammation as represented by blood cytokines 


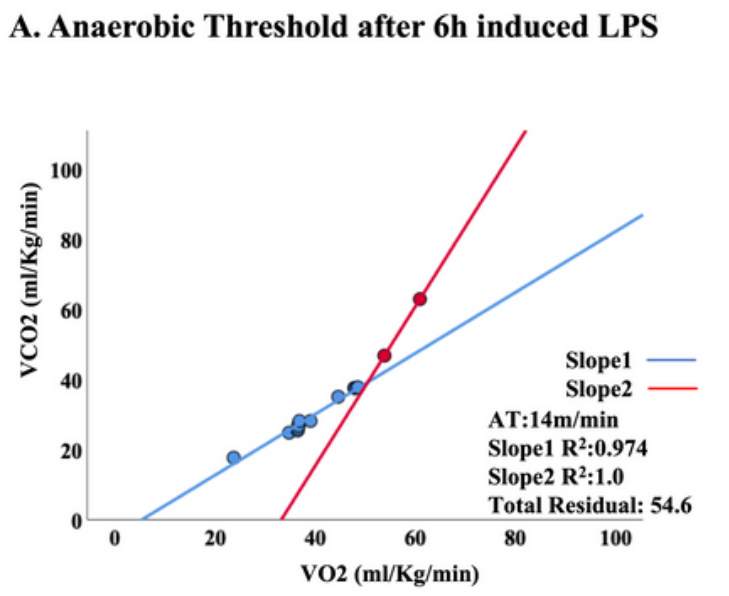

\begin{tabular}{cccccc}
\multicolumn{6}{c}{ Number of subjects at each measurement time point } \\
Speed & Vo2 & Vco2 & $\begin{array}{c}\text { Slope 1 } \\
\text { residuals }\end{array}$ & $\begin{array}{c}\text { Slope 2 } \\
\text { residuals }\end{array}$ & $\begin{array}{c}\text { Total } \\
\text { residuals }\end{array}$ \\
$1 \mathrm{~m} / \mathrm{min}$ & 23.7 & 17.6 & - & - & - \\
$2 \mathrm{~m} / \mathrm{min}$ & 36.7 & 27.4 & 0 & 71.2 & 71.2 \\
$3 \mathrm{~m} / \mathrm{min}$ & 34.7 & 24.8 & 0.7 & 248.5 & 249.2 \\
$4 \mathrm{~m} / \mathrm{min}$ & 36.4 & 25.4 & 1.7 & 228.9 & 230.6 \\
$5 \mathrm{~m} / \mathrm{min}$ & 36.5 & 26 & 1.8 & 211.3 & 213.1 \\
$6 \mathrm{~m} / \mathrm{min}$ & 36.6 & 26.8 & 2 & 197.5 & 199.5 \\
$7 \mathrm{~m} / \mathrm{min}$ & 36.8 & 28.1 & 4.2 & 189.6 & 193.8 \\
$8 \mathrm{~m} / \mathrm{min}$ & 39 & 28.1 & 4.3 & 163.8 & 168.1 \\
$9 \mathrm{~m} / \mathrm{min}$ & 44.6 & 35 & 9.2 & 152.2 & 161.4 \\
$10 \mathrm{~m} / \mathrm{min}$ & 47.8 & 37.5 & 10.8 & 133.3 & 144.1 \\
$12 \mathrm{~m} / \mathrm{min}$ & 48.1 & 37.5 & 11.1 & 101.2 & 112.3 \\
$14 \mathrm{~m} / \mathrm{min}$ & 48.5 & 37.7 & 11.2 & 43.4 & $54.6 *$ \\
$16 \mathrm{~m} / \mathrm{min}$ & 53.8 & 46.8 & - & - & - \\
$18 \mathrm{~m} / \mathrm{min}$ & 60.9 & 62.9 & - & - & -
\end{tabular}

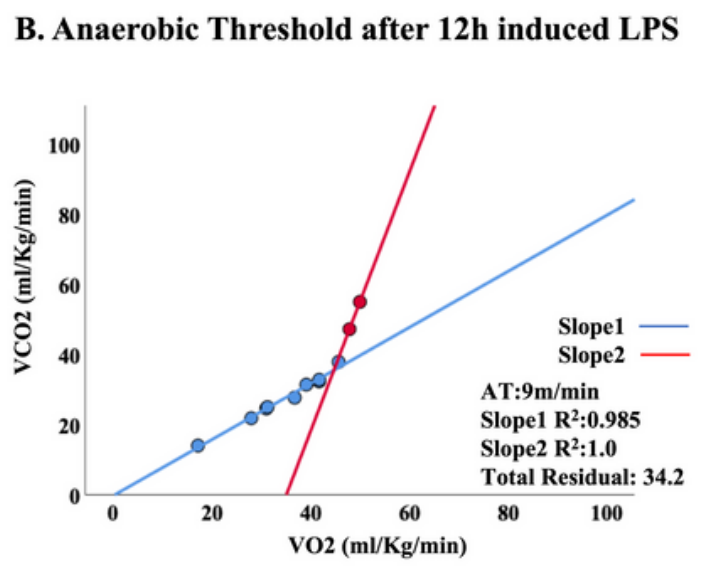

$\begin{array}{cccccc}\text { Speed } & \text { Vo2 } & \text { Vco2 } & \begin{array}{c}\text { Slope 1 } \\ \text { residuals }\end{array} & \begin{array}{c}\text { Slope 2 } \\ \text { residuals }\end{array} & \begin{array}{c}\text { Total } \\ \text { residuals }\end{array} \\ 1 \mathrm{~m} / \mathrm{min} & 17.2 & 14 & - & - & - \\ 2 \mathrm{~m} / \mathrm{min} & 28 & 21.8 & 0 & 11816.7 & 11816.7 \\ 3 \mathrm{~m} / \mathrm{min} & 31 & 24.6 & 0.1 & 193.2 & 193.3 \\ 4 \mathrm{~m} / \mathrm{min} & 31.3 & 25 & 0.2 & 186.1 & 186.3 \\ 5 \mathrm{~m} / \mathrm{min} & 36.8 & 27.3 & 1 & 157.9 & 158.9 \\ 6 \mathrm{~m} / \mathrm{min} & 39.1 & 31.4 & 2.1 & 138.9 & 141 \\ 7 \mathrm{~m} / \mathrm{min} & 41.7 & 32.3 & 2.1 & 93.9 & 96 \\ 8 \mathrm{~m} / \mathrm{min} & 41.7 & 32.8 & 2.2 & 33.8 & 36 \\ 9 \mathrm{~m} / \mathrm{min} & 45.6 & 37.9 & 24.7 & 9.4 & 34.2 \\ 10 \mathrm{~m} / \mathrm{min} & 47.8 & 47.2 & - & - & - \\ 12 \mathrm{~m} / \mathrm{min} & 50 & 55 & - & - & - \\ & & & & & \end{array}$
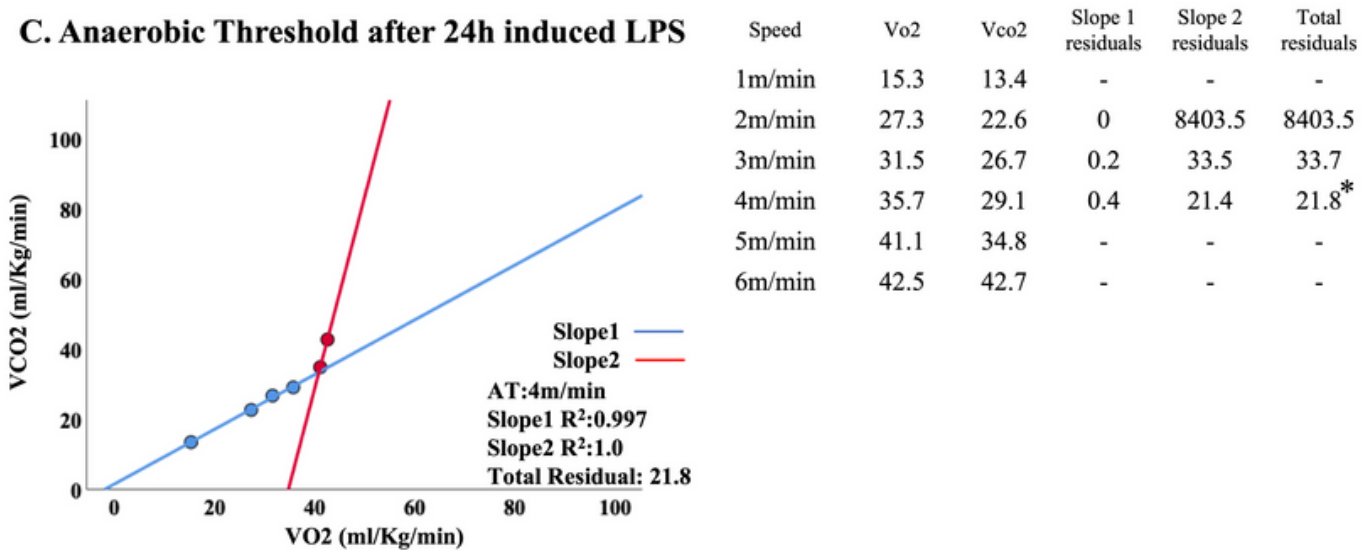

* most fitted point : Anaerobic Threshold

\section{Figure 5}

First day of the AT as estimated by V-slope 


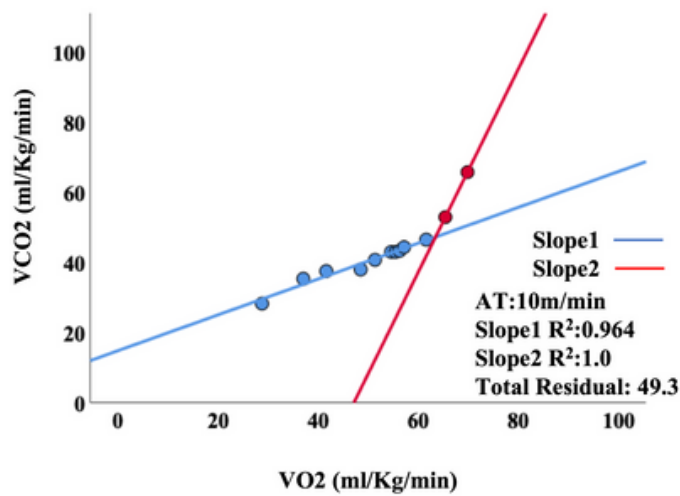

$\begin{array}{cccccc}\text { Speed } & \text { Vo2 } & \text { Vco2 } & \begin{array}{c}\text { Slope 1 } \\ \text { residuals }\end{array} & \begin{array}{c}\text { Slope 2 } \\ \text { residuals }\end{array} & \begin{array}{c}\text { Total } \\ \text { residuals }\end{array} \\ 1 \mathrm{~m} / \mathrm{min} & 28.7 & 28.2 & - & - & - \\ 2 \mathrm{~m} / \mathrm{min} & 37 & 35.3 & 0 & 1212.6 & 1212.6 \\ 3 \mathrm{~m} / \mathrm{min} & 41.6 & 37.5 & 0.8 & 112.2 & 113 \\ 4 \mathrm{~m} / \mathrm{min} & 48.5 & 37.9 & 8.9 & 110.8 & 119.7 \\ 5 \mathrm{~m} / \mathrm{min} & 51.3 & 40.7 & 8.9 & 110 . & 118.9 \\ 6 \mathrm{~m} / \mathrm{min} & 54.5 & 42.9 & 9.1 & 108.3 & 117.4 \\ 7 \mathrm{~m} / \mathrm{min} & 55.5 & 42.9 & 9.1 & 102.9 & 112 \\ 8 \mathrm{~m} / \mathrm{min} & 56.2 & 43.2 & 9.1 & 93.4 & 102.6 \\ 9 \mathrm{~m} / \mathrm{min} & 57.1 & 44.3 & 9.3 & 81.7 & 91 \\ 10 \mathrm{~m} / \mathrm{min} & 61.6 & 46.4 & 9.3 & 40 & 49.3^{*} \\ 12 \mathrm{~m} / \mathrm{min} & 65.4 & 52.9 & - & - & - \\ 14 \mathrm{~m} / \mathrm{min} & 69.8 & 65.7 & - & - & -\end{array}$

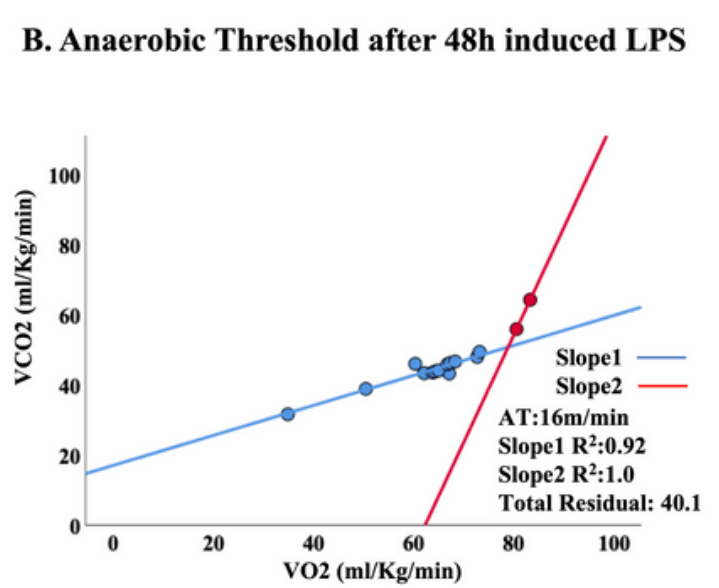

$\begin{array}{cccccc}\text { Speed } & \text { Vo2 } & \text { Vco2 } & \begin{array}{c}\text { Slope 1 } \\ \text { residuals }\end{array} & \begin{array}{c}\text { Slope 2 } \\ \text { residuals }\end{array} & \begin{array}{c}\text { Total } \\ \text { residuals }\end{array} \\ 1 \mathrm{~m} / \mathrm{min} & 34.8 & 31.6 & - & - & - \\ 2 \mathrm{~m} / \mathrm{min} & 50.4 & 38.5 & 0 & 74.7 & 74.7 \\ 3 \mathrm{~m} / \mathrm{min} & 60.3 & 46 & 1.6 & 63.1 & 64.7 \\ 4 \mathrm{~m} / \mathrm{min} & 67.1 & 43.2 & 16.2 & 52.8 & 69 \\ 5 \mathrm{~m} / \mathrm{min} & 62.1 & 43.3 & 16.3 & 52.7 & 69 \\ 6 \mathrm{~m} / \mathrm{min} & 63.8 & 43.5 & 16.7 & 52.2 & 68.9 \\ 7 \mathrm{~m} / \mathrm{min} & 64.2 & 43.8 & 16.8 & 51.4 & 68.3 \\ 8 \mathrm{~m} / \mathrm{min} & 65 & 44 & 16.9 & 50 & 66.9 \\ 9 \mathrm{~m} / \mathrm{min} & 66.7 & 45.9 & 17.5 & 49.5 & 67 \\ 10 \mathrm{~m} / \mathrm{min} & 67.3 & 46.2 & 18 & 48.7 & 66.7 \\ 12 \mathrm{~m} / \mathrm{min} & 68.3 & 46.6 & 18.4 & 46.9 & 65.3 \\ 14 \mathrm{~m} / \mathrm{min} & 72.7 & 48 & 18.4 & 33.5 & 51.9 \\ 16 \mathrm{~m} / \mathrm{min} & 73.2 & 49.4 & 19.8 & 20.3 & 40.1^{*} \\ 18 \mathrm{~m} / \min & 80.5 & 55.9 & - & - & - \\ 20 \mathrm{~m} / \mathrm{min} & 83.3 & 64.2 & - & - & -\end{array}$

* most fitted point : Anaerobic Threshold

\section{Figure 6}

Second day of the AT estimated by V-slope 

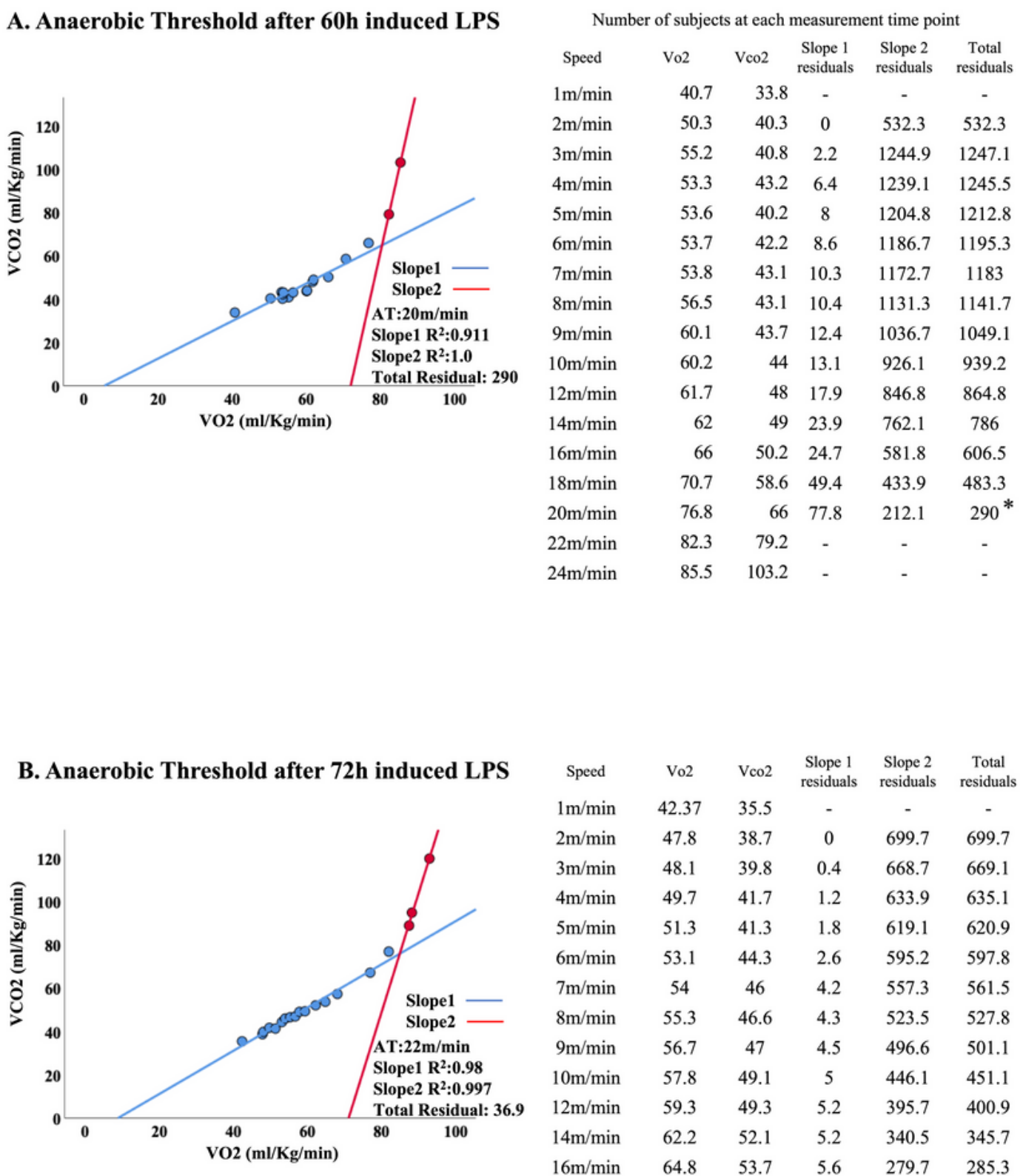

$\begin{array}{cccccc}\text { Speed } & \text { Vo2 } & \text { Vco2 } & \begin{array}{c}\text { Slope 1 } \\ \text { residuals }\end{array} & \begin{array}{c}\text { Slope 2 } \\ \text { residuals }\end{array} & \begin{array}{c}\text { Total } \\ \text { residuals }\end{array} \\ 1 \mathrm{~m} / \mathrm{min} & 42.37 & 35.5 & - & - & - \\ 2 \mathrm{~m} / \mathrm{min} & 47.8 & 38.7 & 0 & 699.7 & 699.7 \\ 3 \mathrm{~m} / \mathrm{min} & 48.1 & 39.8 & 0.4 & 668.7 & 669.1 \\ 4 \mathrm{~m} / \mathrm{min} & 49.7 & 41.7 & 1.2 & 633.9 & 635.1 \\ 5 \mathrm{~m} / \mathrm{min} & 51.3 & 41.3 & 1.8 & 619.1 & 620.9 \\ 6 \mathrm{~m} / \mathrm{min} & 53.1 & 44.3 & 2.6 & 595.2 & 597.8 \\ 7 \mathrm{~m} / \mathrm{min} & 54 & 46 & 4.2 & 557.3 & 561.5 \\ 8 \mathrm{~m} / \mathrm{min} & 55.3 & 46.6 & 4.3 & 523.5 & 527.8 \\ 9 \mathrm{~m} / \mathrm{min} & 56.7 & 47 & 4.5 & 496.6 & 501.1 \\ 10 \mathrm{~m} / \mathrm{min} & 57.8 & 49.1 & 5 & 446.1 & 451.1 \\ 12 \mathrm{~m} / \mathrm{min} & 59.3 & 49.3 & 5.2 & 395.7 & 400.9 \\ 14 \mathrm{~m} / \mathrm{min} & 62.2 & 52.1 & 5.2 & 340.5 & 345.7 \\ 16 \mathrm{~m} / \mathrm{min} & 64.8 & 53.7 & 5.6 & 279.7 & 285.3 \\ 18 \mathrm{~m} / \mathrm{min} & 68.1 & 57.3 & 5.7 & 126 & 131.7 \\ 20 \mathrm{~m} / \mathrm{min} & 77 & 67.2 & 9 & 68.1 & 77.1 \\ 22 \mathrm{~m} / \mathrm{min} & 82 & 77 & 35.1 & 1.7 & 36.8 * \\ 24 \mathrm{~m} / \mathrm{min} & 87.5 & 89 & 105.3 & 0 & 105.3 \\ 26 \mathrm{~m} / \mathrm{min} & 88.2 & 95 & - & - & - \\ 28 \mathrm{~m} / \mathrm{min} & 93 & 120 & - & - & -\end{array}$

* most fitted point : Anaerobic Threshold

\section{Figure 7}

Third day of the AT estimated by V-slope 
25

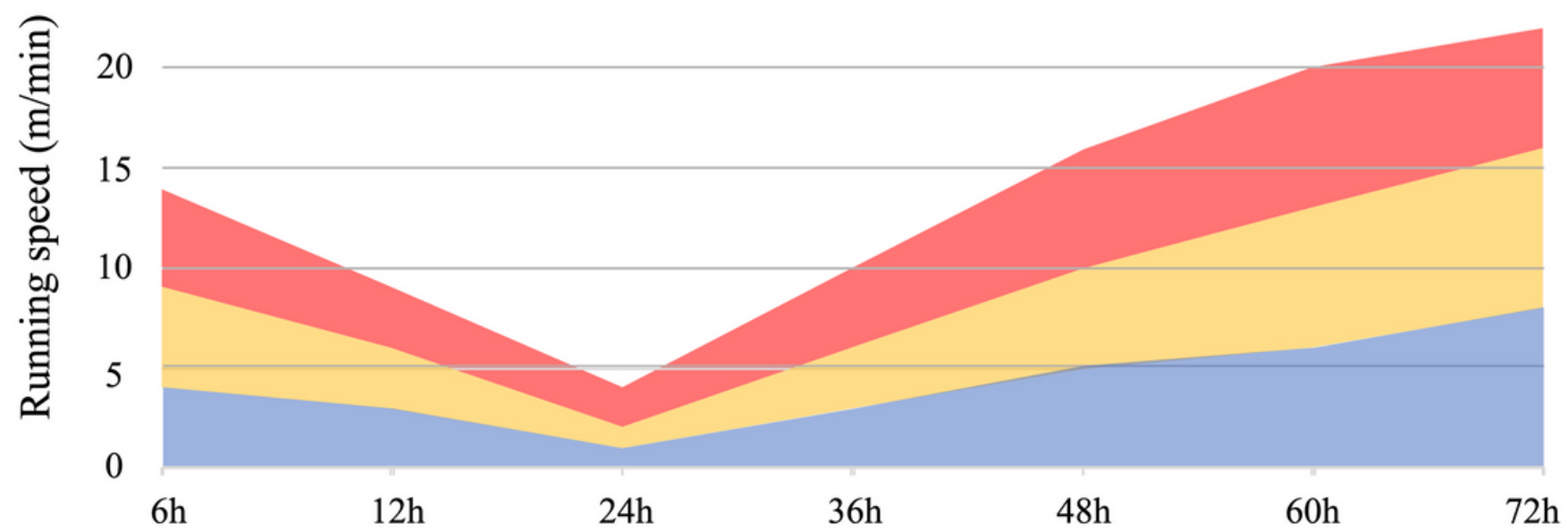

Very low intensity exercise training (VLIT)

Low intensity exercise training (LIT)

Moderate intensity exercise training (MIT)

Number of subjects at each measurement time point

$\begin{array}{cccccccc} & 6 \mathrm{~h} & 12 \mathrm{~h} & 24 \mathrm{~h} & 36 \mathrm{~h} & 48 \mathrm{~h} & 60 \mathrm{~h} & 72 \mathrm{~h} \\ \text { VLIT } & 0 \sim 4 \mathrm{~m} / \mathrm{min} & 0 \sim 3 \mathrm{~m} / \mathrm{min} & 0 \sim 1 \mathrm{~m} / \mathrm{min} & 0 \sim 3 \mathrm{~m} / \mathrm{min} & 0 \sim 5 \mathrm{~m} / \mathrm{min} & 0 \sim 6 \mathrm{~m} / \mathrm{min} & 0 \sim 8 \mathrm{~m} / \mathrm{min} \\ \text { LIT } & 5 \sim 9 \mathrm{~m} / \mathrm{min} & 4 \sim 6 \mathrm{~m} / \mathrm{min} & 2 \mathrm{~m} / \mathrm{min} & 4 \sim 6 \mathrm{~m} / \mathrm{min} & 6 \sim 10 \mathrm{~m} / \mathrm{min} & 7 \sim 13 \mathrm{~m} / \mathrm{min} & 9 \sim 16 \mathrm{~m} / \mathrm{min} \\ \text { MIT } & 10 \sim 14 \mathrm{~m} / \mathrm{min} & 7 \sim 9 \mathrm{~m} / \mathrm{min} & 3 \sim 4 \mathrm{~m} / \mathrm{min} & 7 \sim 10 \mathrm{~m} / \mathrm{min} & 11 \sim 16 \mathrm{~m} / \mathrm{min} & 14 \sim 20 \mathrm{~m} / \mathrm{min} & 17 \sim 22 \mathrm{~m} / \mathrm{min}\end{array}$

\section{Figure 8}

Appropriate intensity of exercise for early mobilization as determined by the V-Slope Method AT was detected at each time point and classified as very low intensity exercise training (VLIT), low intensity exercise training (LIT), or moderate intensity exercise training (MIT). 